\title{
Attentive Study on Strength Characteristics of Expansive Soils on Subgrade of Express Highways by utilisation of RBI Grade-81 and Local Polymers
}

\author{
Kuppili Harish $^{1}$ | Dr. Ch Bhavannarayana ${ }^{2}$ \\ ${ }^{1}$ P.G Student, Kakinada Institute of Engineering \&Technology- II, Korangi, A.P, India. \\ 2 Professor, Kakinada Institute of Engineering \&Technology- II, Korangi, A.P, India.
}

\section{To Cite this Article}

Kuppili Harish and Dr. Ch Bhavannarayana, "Attentive Study on Strength Characteristics of Expansive Soils on Subgrade of Express Highways by utilisation of RBI Grade-81 and Local Polymers", International Journal for Modern Trends in Science and Technology, 6(8): 104-111, 2020.

\section{Article Info}

Received on 21-June-2020, Revised on 15-July-2020, Accepted on 29-July-2020, Published on 06-August-2020.

\section{ABSTRACT}

Chemical stabilization is one of the oldest methods of stabilization of problematic soil. In recent days, it has been investigated that addition of fibers will improve the ductility behavior of the soil there by reducing the development of crack during shrinkage. Extensive study has been carried out on the stabilization of expansive soils using various additives such as RBI, cement, flyash, industrial waste products etc., and also with random inclusion of fibers such as coir, sisal, polyester fibers etc. Randomly oriented tensile inclusions incorporated into soil to improve its load-deformation behaviour by interacting with the soil particles mechanically through surface friction and Effect of Random Inclusion of Coir Fibers on Strength Behaviour of RBI Treated Black Cotton Soil. This project describes the strength behavior of treated black cotton soil (BC soil) reinforced with local fiber. The various percentage of RBI Grade-81 as 2\%, 4\%, 6\% and 8\% was used to find out the optimum value of RBI Grade. local polymer has been randomly included into the RBI Grade treated soil at four different percentages of local fiber content, i.e. 0.5\%, 1\% 1.5\%, and 2\% (by weight of soil).

KEYWORDS: Expansive soil, local polymerr, RBI Grade-81, UCS, shear strength parameters and CBR.

\section{INTRODUCTION}

For any land-based structure, the foundation is very important and has to be strong to support the entire structure. In order of the foundation to be strong, the soil around it plays a very critical role. So, to work with soil we need to have proper knowledge about their properties and factors which affect their behavior. The process of soil stabilization helps to achieve the required properties in a soil needed for the construction work. From the beginning of the construction work, the necessity of enhancing soil properties has come to the light. Ancient civilization of the Chinese,
Romans and Incas utilized various methods to improve the soil strength etc., some of the methods were so effective that their buildings and roads still exist. In India, the modern era of soil stabilization began in early 1970's, with a general shortage of petroleum and aggregates, it became necessary for the engineers to look at means to improve soil other than replacing the poor soil at the building site. Soil stabilization was used but due to the use of obsolete methods and also due to absence of proper technique, soil stabilization lost favor. In recent times, with the increase in the demand for infrastructure, raw materials and fuel, soil 
stabilization has started to take a new shape. With the availability of better research, materials and equipment, it emerging as popular and costeffective method for soil improvement.

\section{MATERIALS FOR STUDY}

Soil Sample:The soil sample used for testing has been collected from muramallavillage of East Godavari district of Andhra Pradesh. The soil sample used for the testing purpose has been taken from depth of about 1.0 to $1.5 \mathrm{~m}$ below ground level.

Properties of Soil Sample:This soil is classified according to I.S classification as inorganic clay of highcompressibility (CH).

Table 1: Properties of Expansive soil

\begin{tabular}{|c|c|c|c|}
\hline Laboratory Test & Symbol & $\begin{array}{c}\text { Result } \\
\mathbf{s} \\
\end{array}$ & \begin{tabular}{|c|}
$\begin{array}{c}\text { Relevant IS } \\
\text { Codes }\end{array}$ \\
\end{tabular} \\
\hline Differential Free Swell & DFS & $110 \%$ & $\begin{array}{c}\text { IS } 2720 \text { Part } \\
\text { XI }\end{array}$ \\
\hline Liquid Limit & WL & $79 \%$ & $\begin{array}{c}\text { IS } 2720 \text { Part } \\
\mathrm{V}\end{array}$ \\
\hline Plastic Limit & WP & $38 \%$ & $\begin{array}{c}\text { IS } 2720 \text { Part } \\
\mathrm{V} \\
\end{array}$ \\
\hline Plasticity Index & PI & $41 \%$ & $\begin{array}{c}\text { IS } 2720 \text { Part } \\
\mathrm{V}\end{array}$ \\
\hline Specific gravity & G & 2.52 & $\begin{array}{c}\text { IS } 2720 \text { Part } \\
\text { III }\end{array}$ \\
\hline \multicolumn{3}{|c|}{ Grain size analysis } & \\
\hline Soil Classification & & $\mathbf{C H}$ & \begin{tabular}{|l} 
IS 2720 Part \\
IV
\end{tabular} \\
\hline \multicolumn{4}{|c|}{ Compaction parameters (Modified Proctor test) } \\
\hline Optimum Moisture content & OMC & $21.42 \%$ & \begin{tabular}{|c|} 
IS 2720 Part \\
VIII \\
\end{tabular} \\
\hline Maximum Dry D & MDD & \begin{tabular}{c|}
15.99 \\
$\mathrm{KN} / \mathrm{m}$ \\
\end{tabular} & $\begin{array}{l}\text { IS } 2720 \text { Part } \\
\text { VIII }\end{array}$ \\
\hline $\begin{array}{l}\text { California Bearing Ratio } \\
\text { (Soaked) }\end{array}$ & CBR & 1.76 & \begin{tabular}{|c|} 
IS 2720 Part \\
XVI \\
\end{tabular} \\
\hline $\begin{array}{l}\text { California Bearing Ratio (Un } \\
\text { Soaked) }\end{array}$ & CBR & 2.6 & $\begin{array}{c}\text { IS } 2720 \text { Part } \\
\text { XVI }\end{array}$ \\
\hline $\begin{array}{l}\text { Unconfined Compressive } \\
\text { Strength }\end{array}$ & UCS & \begin{tabular}{|c|}
$350 K N / m$ \\
2
\end{tabular} & $\begin{array}{c}\text { IS } 2720 \text { Part } \\
\mathrm{X} \\
\end{array}$ \\
\hline $\begin{array}{l}\text { Cohesion } \\
\text { Angle of shearing resista }\end{array}$ & & $\begin{array}{l}0.56 \mathrm{~kg} / \mathrm{c} \\
\mathrm{m}^{2} \\
2 \mathrm{deg}\end{array}$ & IS2720S-11 \\
\hline $\begin{array}{l}\text { Cyclic plate load test } \\
\text { Settlement mm } \\
\text { Load } \mathrm{kN}\end{array}$ & & $\begin{array}{l}3.30 \\
62 \\
\end{array}$ & IS-5249 \\
\hline
\end{tabular}

RBI Grade-81:RBI Grade 81 can be expanded as Road Building International Grade 81. It is a major material which was created for altering the various types of soil through an inexpensive approach. RBI Grade 81 is an ecofriendly, inorganic, hydration activated powder based stabilizer which combines along with the soil particles to create layers that are interconnected through a complex bury atom structure.[patiletall, 2013]. It is a road construction material patented worldwide \& in India. .It is a Cementitious power stabilizer which is grey in color, non-flammable $\&$ also acts as waste binding. It modifies the engineering properties of soil by providing rapid infrastructure development. A Company called Legend Developers in New Delhi supplies RBI Grade 81 (Road Building International Grade 81). The company has the license to manufacture it and has patented it. The product has recently been accredited by Central Road Research Institute, New Delhi. A combination of naturally occurring compounds form RBI Grade 81.Developed Countries like Germany, South Africa, Italy, Spainetc makes use of RBI Grade 81 to a great extent.[venu, 2009] Hence "It is defined as an inorganic chemical stabilizer which modifies the engineering properties of soil."

Coir Fiber: COIR is a versatile natural fibre extracted from monocarp tissue, or husk of the coconut fruit. Generally fibre is of golden colour. It is collected from coir industry.

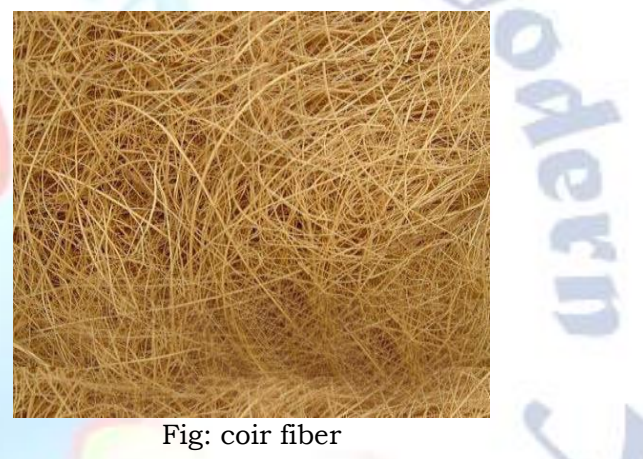

III. RESUlts \& Discussions

Differential Free Swell Index: Standard procedures recommended in the respective I.S. Codes of practice [ IS:2720 (Part-5)-1985; IS:2720 (Part-6)-1972], were followed while finding the DFS viz.

Table 2: Variation of Index Properties of Expansive soil with $6 \%$ of RBI

\begin{tabular}{|c|c|c|}
\hline S.No. & Samples & $\begin{array}{c}\text { DFS } \\
\text { (\%) }\end{array}$ \\
\hline & $100 \% \mathrm{ES}$ & 132 \\
\hline 1 & $\mathbf{9 6 \%} \mathbf{E S}+\mathbf{6 \%} \mathbf{R B I}$ & $\mathbf{8 3}$ \\
\hline 2 & $96 \% \mathrm{ES}+\mathbf{6} \% \mathrm{RBI}+0.5 \% \mathrm{CF}$ & 75 \\
\hline $\mathbf{3}$ & $\mathbf{9 6 \%} \mathbf{E S}+\mathbf{6 \%} \mathbf{R B I}+\mathbf{1 . 0} \% \mathbf{C F}$ & $\mathbf{6 9}$ \\
\hline $\mathbf{4}$ & $96 \% \mathrm{ES}+\mathbf{6} \% \mathrm{RBI}+1.5 \% \mathrm{CF}$ & $\mathbf{5 8}$ \\
\hline 5 & $96 \% \mathrm{ES}+\mathbf{6} \% \mathrm{RBI}+2.0 \% \mathrm{CF}$ & 50 \\
\hline
\end{tabular}




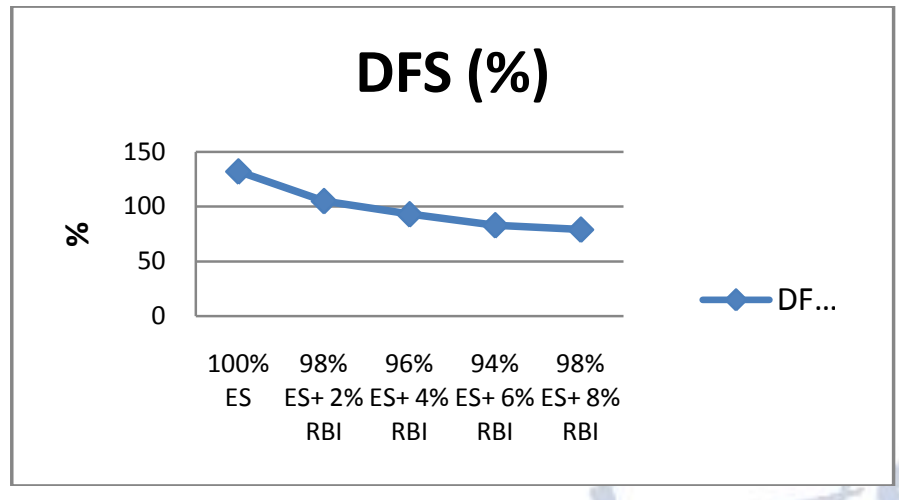

Graph 1: Variation of DFS of ES with different \% of RBI
Table 3Atterberg Limits of $6 \%$ RBI treated Expansive soil and inclusion with Different percentages of Coir Fiber

\begin{tabular}{|c|l|c|c|c|}
\hline S.No. & Samples & $\begin{array}{c}\text { Liquid } \\
\text { Limit } \\
(\%)\end{array}$ & $\begin{array}{c}\text { Plastic } \\
\text { Limit } \\
\text { (\%) }\end{array}$ & $\begin{array}{c}\text { Plasticity } \\
\text { Index (\%) }\end{array}$ \\
\hline 1 & $100 \%$ ES & 79 & 38 & 41 \\
\hline 2 & $\begin{array}{l}96 \% \text { ES+ 6\% } \\
\text { RBI }\end{array}$ & 69 & 48 & 21 \\
\hline 3 & $\begin{array}{l}96 \% \text { ES+ 6\% } \\
\text { RBI+0.5\%CF }\end{array}$ & 65 & 42 & 23 \\
\hline 4 & $\begin{array}{l}96 \% \text { ES+6\% } \\
\text { RBI+1.0\%CF }\end{array}$ & 54 & 43 & 11 \\
\hline 5 & $\begin{array}{l}96 \% \text { ES+6\% } \\
\text { RBI+1.5\%CF }\end{array}$ & 50 & 46 & 4 \\
\hline 6 & $\begin{array}{l}96 \% \text { ES+6\% } \\
\text { RBI+2.0\%CF }\end{array}$ & 48 & 45 & 3 \\
\hline
\end{tabular}

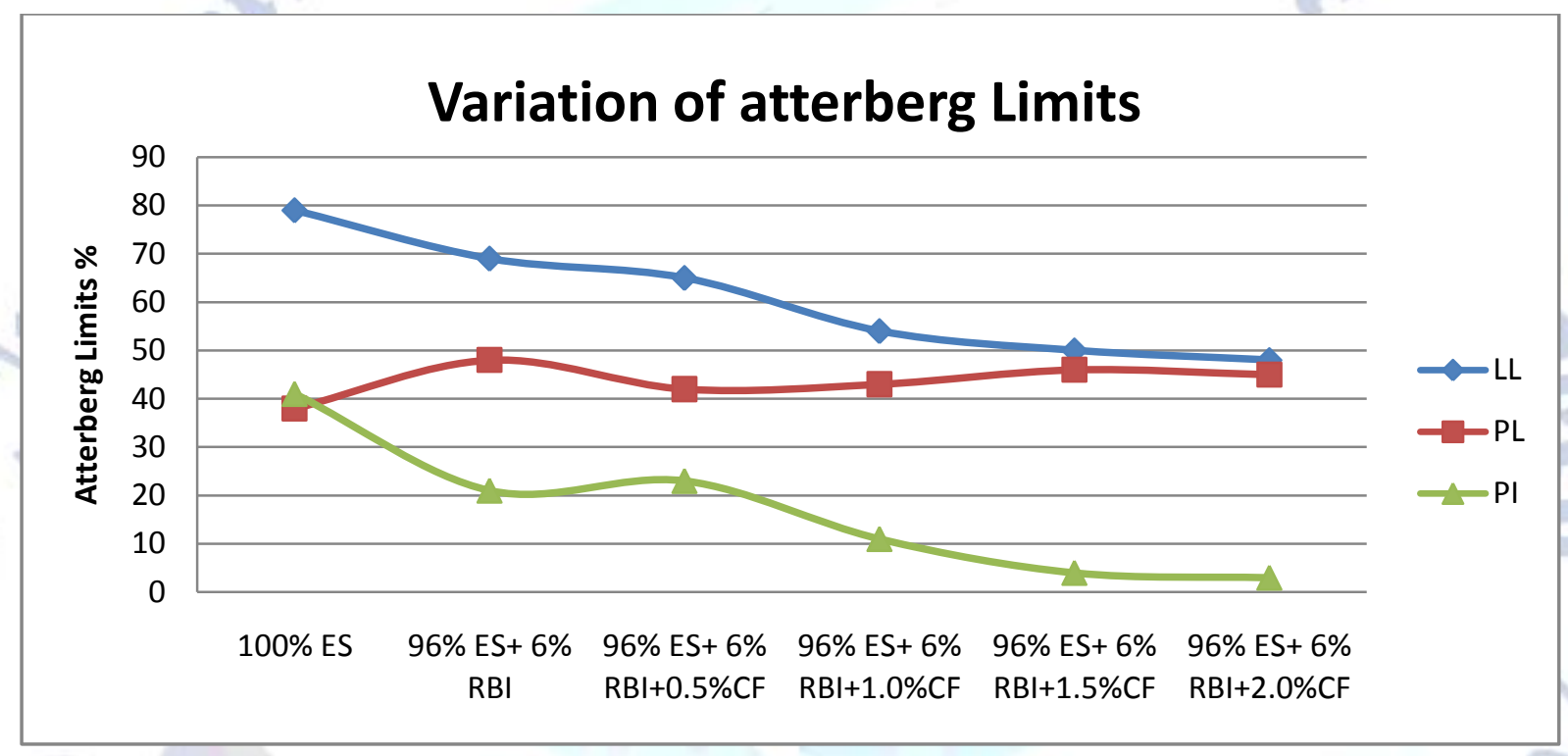

Figure 2 Variation of Atterberg Limits of 6\% RBI treated Expansive soil treated and inclusion with Different percentages of Coir Fiber

Table 4 Compaction Properties of $6 \%$ RBI treated Expansive soil and inclusion with Different percentages of Coir Fiber

\begin{tabular}{|c|c|c|c|}
\hline S.No. & Sample & OMC (\%) & MDD (kN/ $\left.\mathbf{m}^{\mathbf{3}}\right)$ \\
\hline 1 & $100 \% \mathrm{ES}$ & 22.42 & 15.21 \\
\hline 2 & $96 \% \mathrm{ES}+6 \% \mathrm{RBI}$ & 26.4 & 13.23 \\
\hline 3 & $96 \% \mathrm{ES}+6 \% \mathrm{RBI}+0.5 \% \mathrm{CF}$ & 27.23 & 12.3 \\
\hline $\mathbf{4}$ & $96 \% \mathrm{ES}+6 \% \mathrm{RBI}+1.0 \% \mathrm{CF}$ & 31.03 & 11.23 \\
\hline 5 & $96 \% \mathrm{ES}+6 \% \mathrm{RBI}+1.5 \% \mathrm{CF}$ & 34 & 10.23 \\
\hline 6 & $96 \% \mathrm{ES}+6 \% \mathrm{RBI}+2.0 \% \mathrm{CF}$ & 35.23 & 10.2 \\
\hline
\end{tabular}




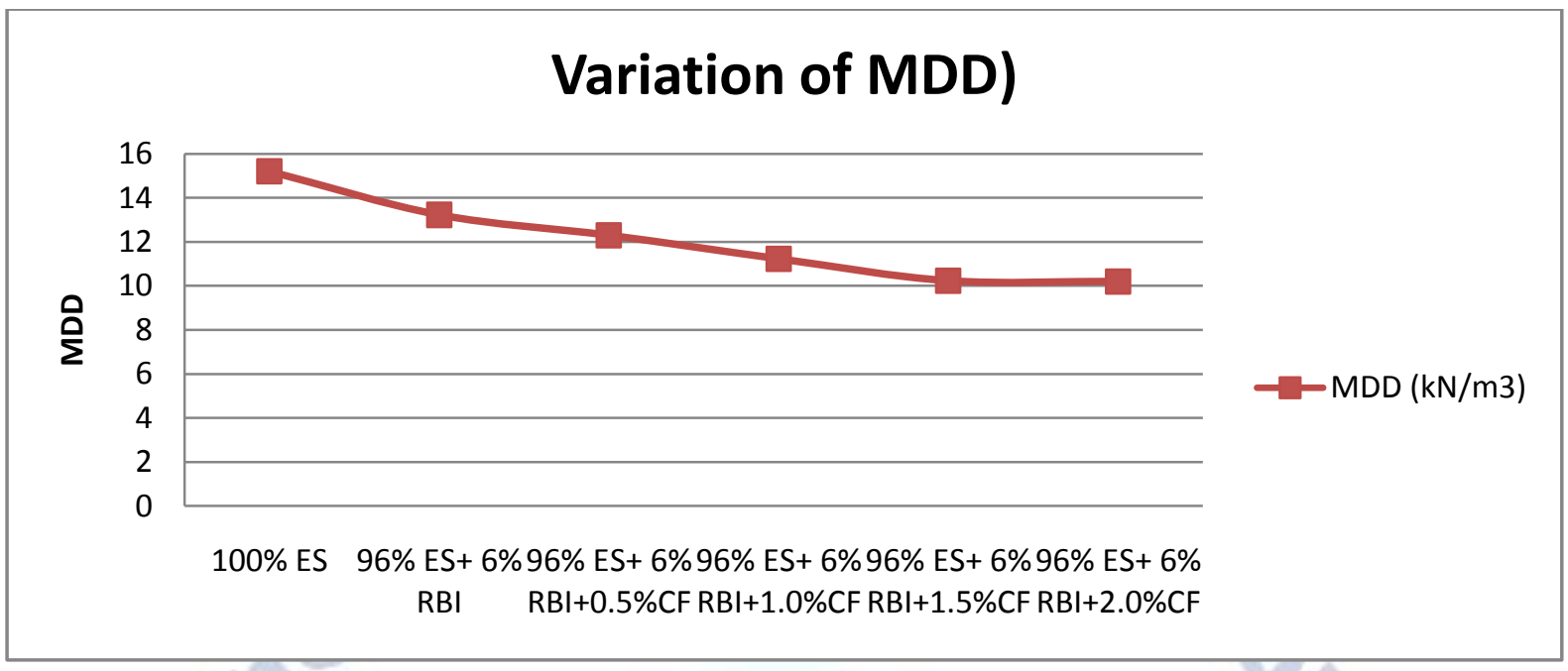

Figure 3 Variation of compaction properties (OMC) of 6\% RBI treated Expansive soil treated and inclusion with Different percentages of Coir Fiber

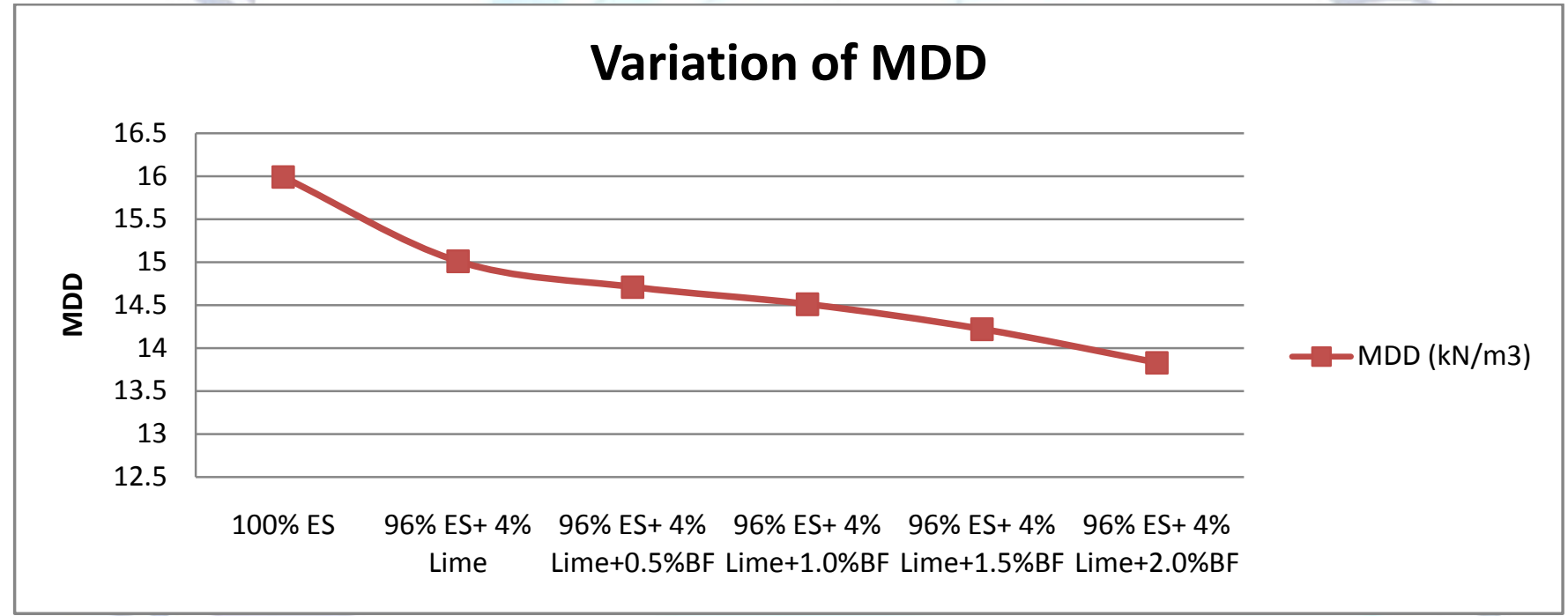

Figure 4 Variation of compaction properties (MDD) of 6\% RBI treated Expansive soil treated and inclusion with Different percentages of Coir Fiber

Table 5 CBR (Un-Soaked \& Soaked) of 6\% RBI treated Expansive soil and inclusion with Different percentages of Coir Fiber

\begin{tabular}{|c|c|c|c|}
\hline S.No & Sample & Un Soaked CBR (\%) & Soaked CBR (\%) \\
\hline 1 & $100 \% \mathrm{ES}$ & 2.26 & 1.89 \\
\hline 2 & $96 \% \mathrm{ES}+6 \% \mathrm{RBI}$ & 7.6 & 4.23 \\
\hline 3 & $98 \% \mathrm{ES}+6 \% \mathrm{RBI}+0.5 \% \mathrm{CF}$ & 8.29 & 5.23 \\
\hline $\mathbf{4}$ & $96 \% \mathrm{ES}+6 \% \mathrm{RBI}+1.0 \% \mathrm{CF}$ & 10.23 & 6.86 \\
\hline 5 & $96 \% \mathrm{ES}+6 \% \mathrm{RBI}+1.5 \% \mathrm{CF}$ & 10.23 & 6.7 \\
\hline 6 & $96 \% \mathrm{ES}+6 \% \mathrm{RBI}+2.0 \% \mathrm{CF}$ & 9.2 & 6.5 \\
\hline
\end{tabular}




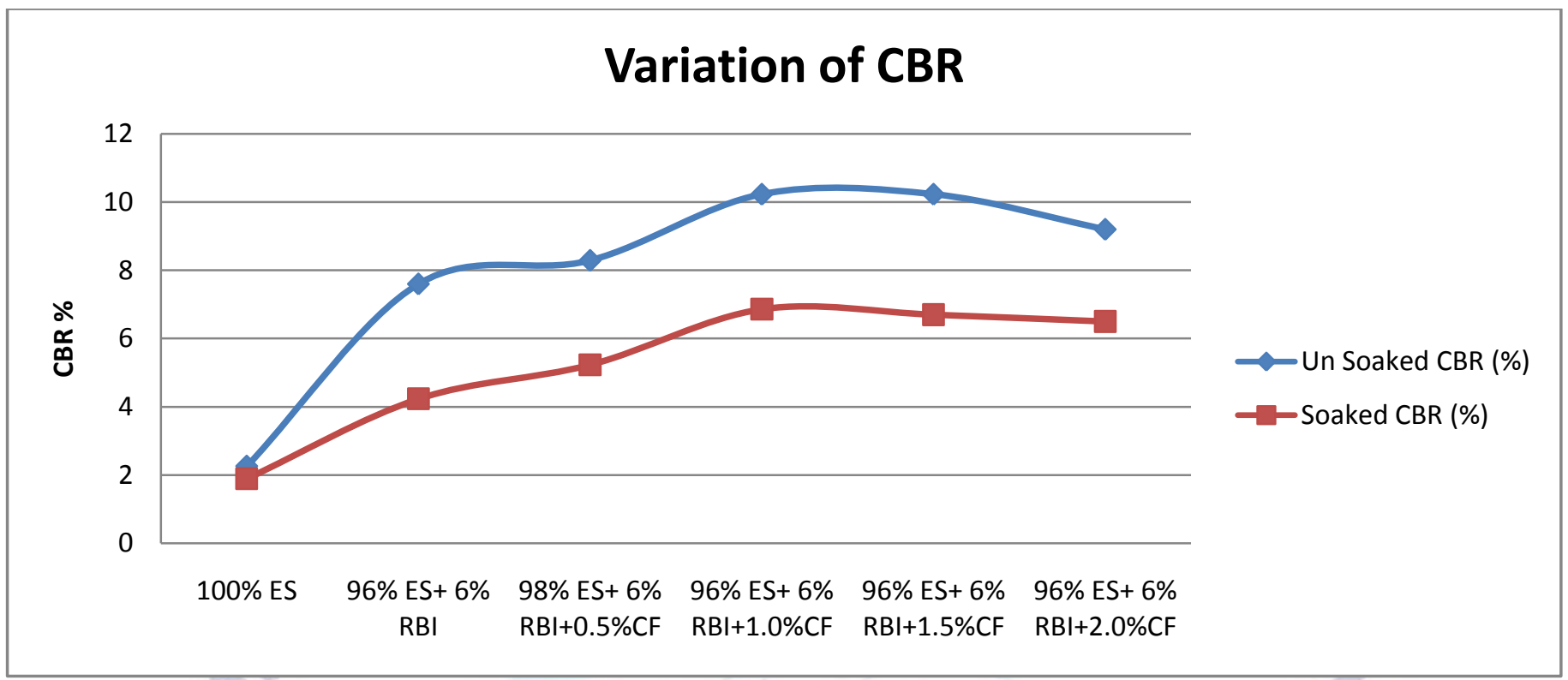

Figure 5. Variation of CBR (Un-Soaked \& Soaked) of 6\% RBI treated Expansive soil treated and inclusion with Different percentages of Coir Fiber.

Table 6 UCS of 6\% RBI treated Expansive soil and inclusion with Different percentages of Coir Fiber

\begin{tabular}{|c|c|c|c|c|c|}
\hline \multirow{2}{*}{ S No } & \multirow{2}{*}{ Particulars } & \multicolumn{4}{|c|}{ Days UCS(kN/ m2) } \\
\cline { 2 - 5 } & & $\mathbf{0}$ & $\mathbf{7}$ & $\mathbf{1 4}$ & $\mathbf{2 8}$ \\
\hline 1 & $100 \% \mathrm{ES}$ & 350 & 350 & 350 & 350 \\
\hline 2 & $96 \% \mathrm{ES}+6 \% \mathrm{RBI}$ & 823 & 956 & 1050 & 1105 \\
\hline 3 & $96 \% \mathrm{ES}+6 \% \mathrm{RBI}+0.5 \% \mathrm{CF}$ & 960 & 1140 & 1220 & 1340 \\
\hline $\mathbf{4}$ & $96 \% \mathrm{ES}+6 \% \mathrm{RBI}+1.0 \% \mathrm{CF}$ & 1110 & 1370 & 1560 & 1690 \\
\hline 5 & $96 \% \mathrm{ES}+6 \% \mathrm{RBI}+1.5 \% \mathrm{CF}$ & 1020 & 1220 & 1340 & 1480 \\
\hline 6 & $96 \% \mathrm{ES}+6 \% \mathrm{RBI}+2.0 \% \mathrm{CF}$ & 960 & 1100 & 1250 & 1300 \\
\hline
\end{tabular}

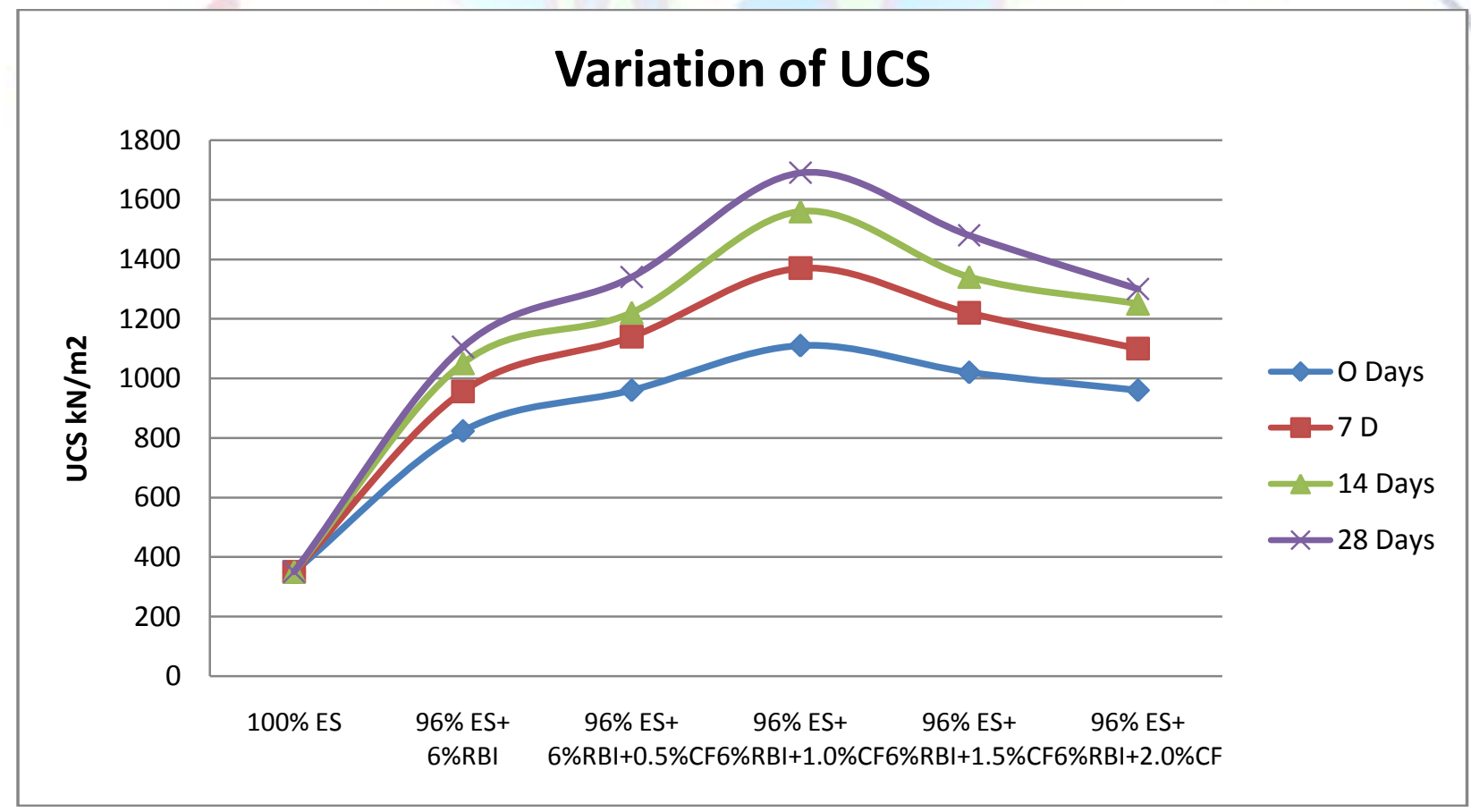

Figure 6 Variation of UCS of 6\% RBI treated Expansive soil treated and inclusion with Different percentages of Coir Fiber

Note: 6\% RBI treated Expansive soil and inclusion of different percentages of Coir Fiberi.e $0.5 \%$ to 2\%. 
Table 7 Variation of Shear strength parameters with the addition of RBI \& Coir Fiber to the expansive clay

\begin{tabular}{|c|c|c|c|c|c|c|}
\hline \multirow[b]{3}{*}{ Particulars } & \multicolumn{6}{|c|}{ Shear Strength Properties } \\
\hline & \multicolumn{2}{|c|}{1 day } & \multicolumn{2}{|c|}{7 days } & \multicolumn{2}{|c|}{ 14days } \\
\hline & $\begin{array}{c}\text { Cohesion, } \\
\mathbf{C}_{\mathrm{u}} \\
\left(\mathrm{kg} / \mathrm{cm}^{2}\right)\end{array}$ & $\begin{array}{c}\text { Angle of } \\
\text { internal } \\
\text { friction, } \square, \\
\text { (Deg.) }\end{array}$ & $\begin{array}{c}\text { Cohesion, } \\
\mathbf{C}_{\mathrm{u}} \\
\left(\mathrm{kg} / \mathrm{cm}^{2}\right)\end{array}$ & $\begin{array}{c}\text { Angle of } \\
\text { internal } \\
\text { friction, } \square \text {, } \\
\text { (Deg.) }\end{array}$ & $\begin{array}{c}\text { Cohesion, } \\
\mathbf{C}_{\mathrm{u}} \\
\left(\mathbf{k g} / \mathrm{cm}^{2}\right)\end{array}$ & $\begin{array}{c}\text { Angle of } \\
\text { internal } \\
\text { friction, } \square \text {, } \\
\text { (Deg.) }\end{array}$ \\
\hline $100 \% \mathrm{ES}$ & 0.9 & 7 & 0.95 & 8 & 0.99 & 8 \\
\hline $98 \% \mathrm{ES}+2 \% \mathrm{RBI}$ & 0.9 & 7 & 0.88 & 6 & 0.85 & 5 \\
\hline $96 \% \mathrm{ES}+4 \% \mathrm{RBI}$ & 0.95 & 6 & 0.9 & 5 & 0.88 & 4 \\
\hline $94 \% \mathrm{ES}+6 \% \mathrm{RBI}$ & 0.96 & 6 & 0.87 & 5 & 0.77 & 4 \\
\hline $92 \% \mathrm{ES}+8 \% \mathrm{RBI}$ & 0.7 & 5 & 0.68 & 4 & 0.65 & 4 \\
\hline $100 \% \mathrm{ES}$ & 0.85 & 8 & 0.85 & 8 & 0.85 & 8 \\
\hline $96 \% \mathrm{ES}+6 \% \mathrm{RBI}$ & 0.95 & 6 & 0.9 & 5 & 0.88 & 4 \\
\hline $96 \% \mathrm{ES}+6 \% \mathrm{RBI}+0.5 \% \mathrm{CF}$ & 0.98 & 5 & 0.99 & 4 & 1 & 3 \\
\hline $96 \% \mathrm{ES}+6 \% \mathrm{RBI}+1.0 \% \mathrm{CF}$ & 1.2 & 4 & 1.25 & 3 & 1.41 & 2 \\
\hline $96 \% \mathrm{ES}+6 \% \mathrm{RBI}+1.5 \% \mathrm{CF}$ & 0.9 & 3 & 0.9 & 2 & 1 & 2 \\
\hline $96 \% \mathrm{ES}+6 \% \mathrm{RBI}+2.0 \% \mathrm{CF}$ & 0.85 & 3 & 0.84 & 2 & 0.9 & 1 \\
\hline
\end{tabular}

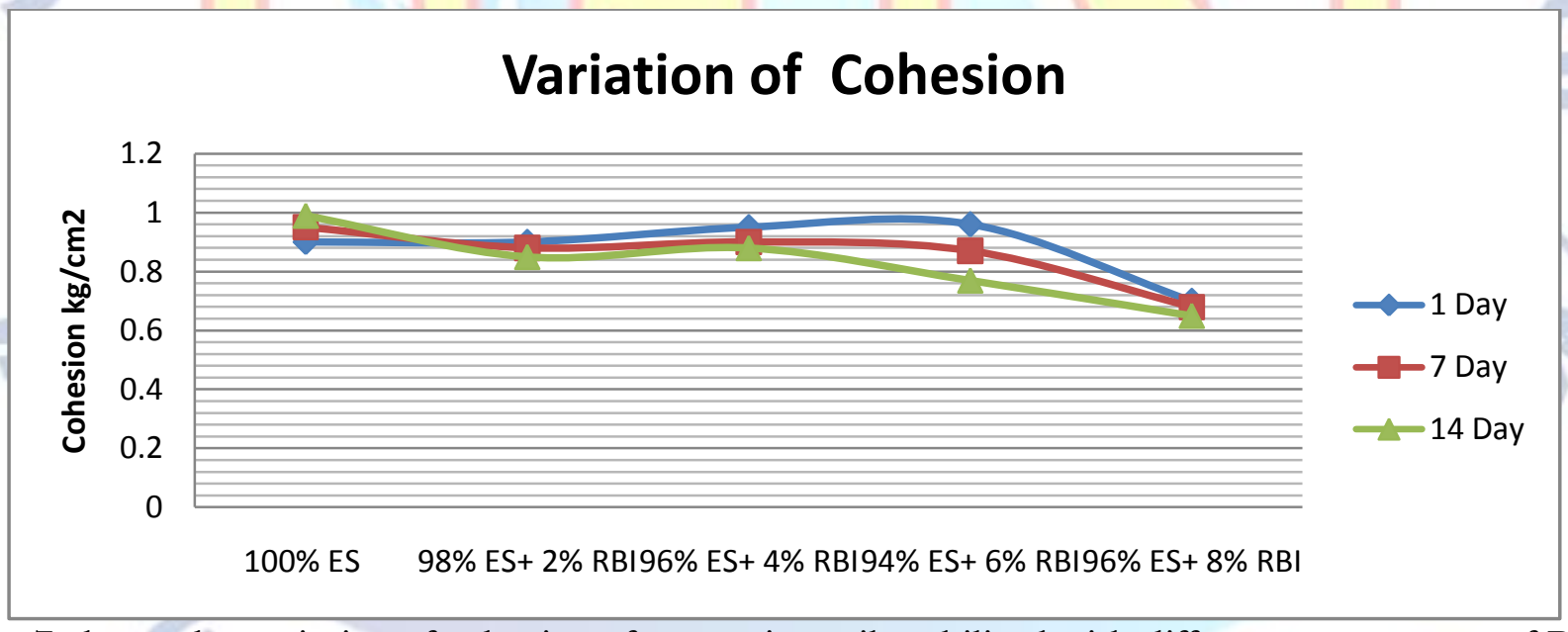

Fig. 7 shows the variation of cohesion of expansive soil stabilized with different percentages of RBI 


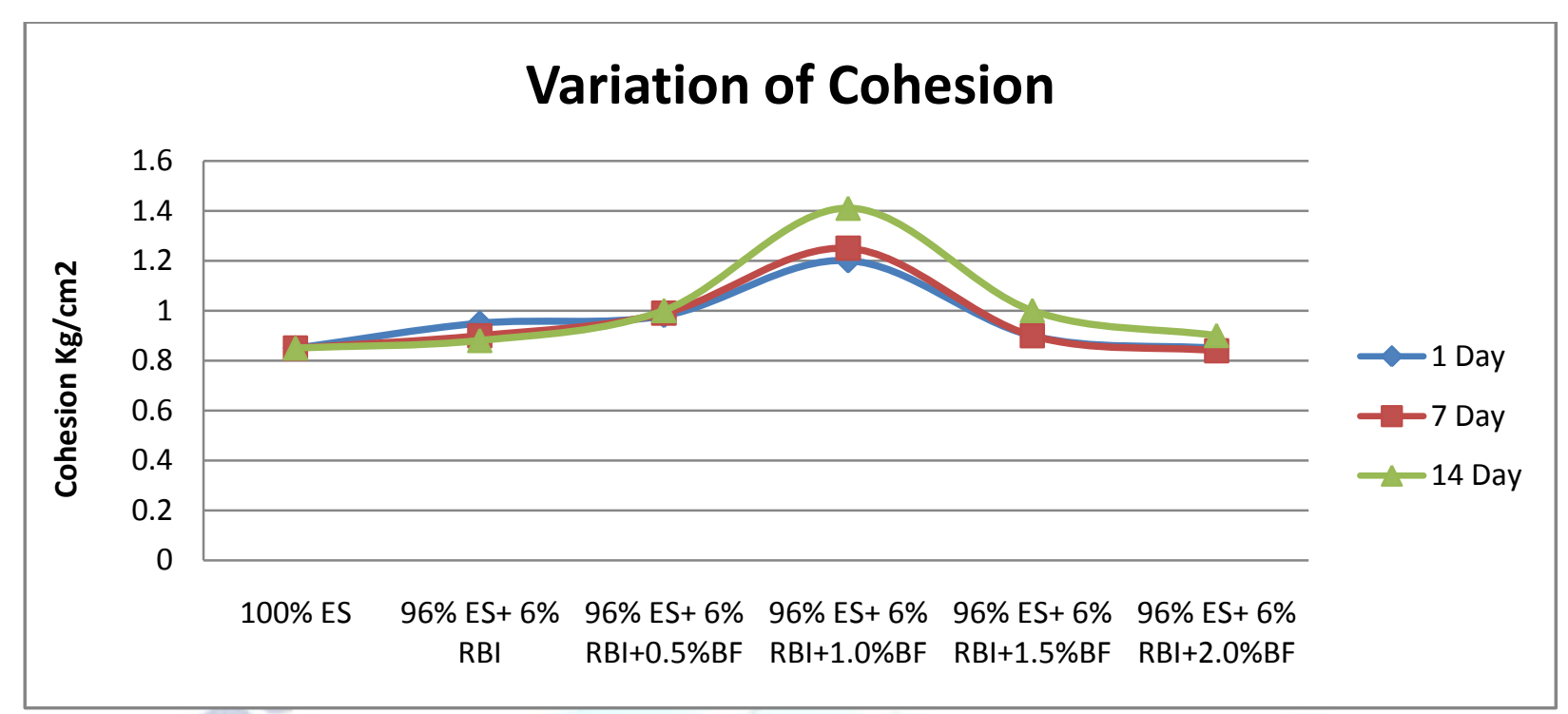

Fig. 8Shows the variation of cohesion of expansive soil stabilized with different percentages of Coir Fiber.

\section{Conclusions}

Based on the results presented in this paper, the following conclusions are drawn.

$>$ RBI treated $\mathrm{BC}$ soil reinforced with $1 \%$ coir fiber increases the strength and reduces the brittle behaviour of soil specimen, where as the other percentages of fibers used shows a marginal increase.

$>$ This paper evaluated the effect of coir fibre on the strength and compaction characteristics of RBI treated black cotton soil. A series of tests were performed to study the effects of RBI on strength characteristics of black cotton soil.

$>$ For a given coir fibre percentage contents in the compaction tests, the maximum dry density of stabilized soil decreased and optimum moisture content increased. The maximum dry density of coir fibre reinforced with $6 \%$ RBI treated soil decreased the density value and OMC value.

$>$ Addition of various percentages of RBI to black cotton soil gives increased value in the unconfined compressive strength upto $6 \%$ and addition of RBI with Coir fibre also gave increase in compressive strength upto $1.0 \%$ Coir fibre.

$>$ The curing period with addition of RBI and Coir fibre gave higher strength values. Hence, $6 \%$ of RBI content and $1.0 \%$ of Coir fibre is considered as optimum percentages for black cotton soil.

$>$ Addition of various percentages of RBI to black cotton soil gave increased value in the CBR upto $6 \%$ as we can observe in graph. Then the addition of Coir fibre gave increased value of CBR for 1.0 coir fibre.
$>$ The combination of $6 \% \mathrm{RBI}$ and $1.0 \%$ Coir fibre gives more increased value than addition of RBI and Coir fibre. Hence, $6 \%$ of RBI content and $1.0 \%$ of Coir fibre can be considered as optimum percentages for black cotton soil to increase the CBR value.

$>$ Addition of RBI has shown decrement in DFS from $132 \%$ to $83 \%$ when the RBI at optimum and $2 \% \mathrm{BF}$ content mixed in expansive soil as a result of cation ions from the RBI which reduces the volumetric changes. The percentage decreases $67 \%$.

Addition of RBI has shown decrement in liquid limit from $84 \%$ to $68 \%$ and improvement in plastic limit from $35 \%$ to $49 \%$ and plasticity index decrease from $49 \%$ to $19 \%$ when the RBI content varies from $0 \%$ to $8 \%$ with an increment of $2 \%$ mixed in expansive soil as a result of cation ions from the RBI which reduces the volumetric changes.

$>$ Addition of RBI to the black cotton soil results the decreases the MDD valuefrom $15.21 \mathrm{KN} / \mathrm{m}^{3}$ to $13.23 \mathrm{KN} / \mathrm{m}^{3}$ whereas OMC increases from $22.42 \%$ to $26.40 \%$ at $6 \%$ of RBI.

Compaction characteristics of treated expansive soil- RBI mix at optimum $6 \%$ of RBI, OMC increasing from $22.21 \%$ to $35.23 \%$ and $\mathrm{MDD}$ decreasing from $15.21 \mathrm{KN} / \mathrm{m}^{3}$ to $10.20 \mathrm{kN} / \mathrm{m}^{3}$ with the addition of different percentages of fibers ranges from 0.5 to $2 \%$ with an increment of $1 \%$ of bamboo fiber.

$>$ On comparing the CBR values it is found that we got better CBR value when the soil is treated 
with both the RBI and bamboo fiber than untreated soil.

> Addition of RBI to expansive soil, Un-soaked CBR values increases from $2.26 \%$ to $5.58 \%$ up to $6 \%$ of RBI and beyond the value decreases. Hence, the optimum percentage of RBI is $6 \%$.

$>$ Addition of RBI to expansive soil, Soaked CBR values increases from $1.89 \%$ to $4.1 \%$ up to $6 \%$ of RBI and beyond the value decreases. Hence, the optimum percentage of RBI is $6 \%$.

> Un-soaked CBR value goes increasing from $2.26 \%$ to $9.2 \%$ up to theaddition of $1 \%$ fiber to RBI treated soil, beyond it is decreased with further addition fibber. Hence, the optimum percentage of fiber is $1 \%$.

> Soaked CBR value goes increasing from $1.89 \%$ to $6.5 \%$ up to the additionof $1 \%$ fiber to RBI treated soil, beyond it is decreased with further addition fibber. Hence, the optimum percentage of fiber is $1 \%$.

$>$ From the UCS test, it is obtained that the unconfined compressive strength of expansive soil is increasing with optimum of RBI i.e.6\% and the addition of Coir fiber up to $1 \%$ and beyond it is decreased.

> At 0 Days, The Unconfined compressive strength value increases from $360 \mathrm{KN} / \mathrm{m} 2$ of black cotton soil to $800 \mathrm{KN} / \mathrm{m} 2$ at $6 \%$ of RBI and reached to $1110 \mathrm{KN} / \mathrm{m} 2$ at $1 \%$ Coir fiber with RBI blended soil. From it is concluded that $1 \%$ coir fiber is optimum.

At 7 Days, The Unconfined compressive strength value increases from $360 \mathrm{KN} / \mathrm{m} 2$ of black cotton soil to $910 \mathrm{KN} / \mathrm{m} 2$ at $6 \%$ of RBI and reached to $956 \mathrm{KN} / \mathrm{m} 2$ at $1 \%$ coir fiber with $\mathrm{RBI}$ blended soil. From it is concluded that $1 \%$ coir fiber is optimum.

> At 14 Days, The Unconfined compressive strength value increases from $360 \mathrm{KN} / \mathrm{m} 2$ of black cotton soil to $1050 \mathrm{KN} / \mathrm{m} 2$ at $6 \%$ of RBI and reached to $1560 \mathrm{KN} / \mathrm{m} 2$ at $1 \%$ coir fiber with RBI blended soil. From it is concluded that $1 \%$ coir fiber is optimum.

> At 28 Days, The Unconfined compressive strength value increases from $360 \mathrm{KN} / \mathrm{m} 2$ of black cotton soil to $1105 \mathrm{KN} / \mathrm{m} 2$ at $6 \%$ of $\mathrm{RBI}$ and reached to $1690 \mathrm{KN} / \mathrm{m} 2$ at $1 \%$ coir fiber with RBI blended soil. From it is concluded that $1 \%$ coir fiber is optimum.

$>$ Overall it can be concluded that RBI and fiber stabilized soil can be considered to be good ground improvement technique especially in engineering projects on weak soils from economic consideration.

\section{REFERENCES}

[1] Ramesh, H.N., K.V. Manoj Krishna and H.V. Mamatha (2010) "Compaction and strength behaviour of RBI-coir fiber treated black cotton soil", geomechanics and Engineering, Vol. 2., No. 1 19-28.

[2] Kaniraj, S.R. and Vasant, G.H. (2001), "Behavior of cement-stabilized fiber reinforced fly ash soil mixture",Geotech. Geoenviron. Eng. J, 574-584.

[3] Kaniraj, S.R. and Gayathri, V. (2003), "Geotechnical Behavior of fly ash mixed with randomly oriented fiber inclusions", Geotext. Geomembranes, 21, 123-149.

[4] Nagu, P.S., Chandrakaran, S. and Sankar, N. (2008), "Behaviour of RBI stabilized clayey soil reinforced with Nylon fibers", Proceedings of '08 International Conference on Geotechnical and Highway Engineering, Geotropika, Kuala Lumpar, Malaysia, May.

[5] Kavitha. S and Dr. T. Felix Kala, "Bamboo Fibre Analysis by Scanning Electron Microscope Study". International Journal of Civil Engineering and Technology (IJCIET), 7(4), 2016, pp.234-24.

[6] Experimental and Modeling Results for Fiber-Reinforced Clay”, Int. J. Geomech.,(ASCE), 13(6): 882-893 